\title{
Comparison of the chemical quality of rainwater harvested from roof and surface run-off systems
}

\author{
MS Selala', H Thenga', GPW Jewitt ${ }^{1,2}$ and V Chaplot ${ }^{1,3 *}$ \\ 'Centre for Water Resources Research, School of Agricultural, Earth \& Environmental Sciences, Rabie Saunders Building, \\ University of KwaZulu-Natal, South Africa \\ ${ }^{2} U$ mgeni Water Chair of Water Resources Management, School of Engineering, University of KwaZulu-Natal, South Africa \\ ${ }^{3}$ Institut de Recherche pour le Développement (IRD), Laboratoire d'Océanographie et du Climat (LOCEAN), IPSL, Université Pierre et Marie Curie, \\ 4, place Jussieu 75252 Paris Cedex 05, France
}

\begin{abstract}
Despite numerous studies, little is known about the quality of rainwater harvested (RWH) from roofs or overland flow by smallholder farmers of Africa. Thus, the main objective of this study was to compare the physical and chemical quality of the rainwater harvested from both dwelling roofs and yards situated in a smallholder community in KwaZulu-Natal (South Africa). Rainwater samples were collected at 51 households during a dry period for assessment of the concentration of specific chemical elements. The water harvested from metallic roofs and yards did not meet the World Health Organization (WHO, 2011) guidelines for drinking water, as it exceeded recommended levels of Se, $\mathrm{Al}, \mathrm{B}$ and $\mathrm{Cd}$ in at least $75 \%$ of the roof water samples, and of $\mathrm{Al}$ in the case of yard RWH. Compared to yard water, RWH from metallic roofs exhibited higher $\mathrm{B}, \mathrm{Se}, \mathrm{Ni}, \mathrm{Pb}$, $\mathrm{Cu}, \mathrm{As}, \mathrm{Cd}$, and $\mathrm{Cr}$ but lower dissolved organic carbon (DOC), $\mathrm{NO}_{3}^{-}, \mathrm{Fe}, \mathrm{SO}_{4}^{2-}, \mathrm{Na}, \mathrm{Mg}, \mathrm{Ca}, \mathrm{K}, \mathrm{Fe}$ concentrations. The content of nutrients and DOC in the water harvested from the surface correlated with the number of pigs per household (with $r=0.78$ for $\mathrm{SO}_{4}^{2-}, r=0.74$ for DOC and $r=0.52 ; \mathrm{NO}_{3}^{-}$). These results are expected to inform improved design and implementation of RWH. Further investigations should consider both physicochemical and microbiological aspects of water quality to provide a more holistic understanding of potential health risks.
\end{abstract}

Keywords: rainwater harvesting, roof-harvested rainwater, pollution, human health, food security, Africa, rural

\section{INTRODUCTION}

A large proportion of the population of arid and semi-arid regions of the world do not have access to safe drinking water. The main reason for this is that major freshwater supplies in the drylands come from sources (either surface: stream, rivers and lakes, or subsurface: boreholes and wells) of low reliability (Li et al., 2004; Radaideh et al., 2009; Al-Salayman et al., 2011). Moreover, the majority of rural areas in these regions are not connected to water supply networks and the costs of exploiting available resources are relatively high. Rainwater harvesting (RWH) thus appears a promising alternative source of freshwater (Pacey and Cullis, 1986; Zhu et al., 2004; Barron and Okwach, 2005; Sturm et al., 2009; Bulcock and Jewitt, 2013), providing opportunities for socio-economic development in these largely impoverished areas (Kahinda et al., 2007).

RWH in a broad sense is defined as the collection, storage and use of runoff from rainwater. Different RWH techniques exist and are categorised into two major groups. The first consists of in-situ techniques such as mulching or zero tillage, where rainfall is collected and stored in the soil. The second group includes external techniques of collecting runoff from, for instance, roofs, streets, roads and courtyards, and storing it off-site, such as in drums, large plastic containers or dams (Helmreich and Horn, 2009; Bulcock and Jewitt, 2013). Most RWH in rural areas is practised for domestic purposes such as drinking, cooking, washing and gardening (Radaideh et al., 2009). Specifically, rooftop RWH is mainly used for drinking and cooking, while water harvested from streets and courtyards

\footnotetext{
* To whom all correspondence should be addressed.

e-mail: vincent.chaplot@ird.fr

Received 18 December 2015; accepted in revised form 26 March 2018
}

is used for agriculture (Zhu et al., 2004). RWH provides other benefits. Not only does it fulfil the domestic demand for water but reportedly shows great potential for reducing soil erosion and flooding risk (Zhu et al., 2004; Schiettecatte et al., 2005; Bossio et al., 2011).

There are contradictory results concerning the quality of the water harvested from the different sources. Zhu et al. (2004), in a study of RWH from both roofs and streets in China, showed that only roof-harvested water meets the World Health Organisation (WHO, 2011) standards for drinking water, with the street water showing high concentrations of organic chemicals. Similarly, studies by Mendez et al. (2010) and Lee et al. (2012) confirmed the potability of roof water compared to other water sources. In Nigeria, Efe (2006), who investigated the quality of rainwater harvested from rooftops made of different materials (thatch, aluminium, asbestos and corrugated sheet), found that most of the physico-chemical and biological characteristics of the rainwater samples meet the WHO guidelines for drinking water, except for $\mathrm{pH}$, total dissolved solids (TSS), colour and Iron (Fe). However, Kus et al. (2010) pointed out that, despite the harvested water being initially potable, further chemical or microbial contamination may occur during storage, thus pointing to the need to assess the quality of the harvested water when it is utilised by endusers, which is generally during the dry season and several months after it is harvested..

In rural areas of South Africa, hut roofs and bare yards from around households have a great potential for RWH because of their impermeable nature and their proximity to the users. Yet, little is known about the quality of the water harvested from these two surfaces and specifically the impact of the nearby environment of yards, such as its surface area, and the number of people and domesticated animals in the 
household, on the harvested water. Several studies performed under different environments have pointed to microbial contamination of the harvested water, contamination with nutrients and metals, along with pathogenic microorganisms such as protozoa, helminths, viruses, and bacteria being washed into storage tanks during storm events (Al-Khatib and Orabi, 2004), with direct impacts on human health (Kong et al., 2009; Dobrowsky et al., 2014). Potential health effects from long exposure to chemical elements and certain physical characteristics have been documented. For instance, long-term exposure to copper and cadmium may damage the kidney while arsenic increases the risk of getting cancer (Järup, 2003). In addition, high turbidity levels from soil runoff have been associated with higher levels of disease-causing microorganisms such as viruses, parasites and some bacteria (Jain et al., 2010).

The objectives of this study were therefore (i) to ascertain the impact of the RWH sources (roof and yard), commonly used in the rural communities of Southern Africa on water quality; and (ii) to evaluate to what extent selected environmental and human factors such as the yard surface area, and the number of people and livestock in the household, might affect the quality of harvested rainwater. In this study, selected physical and chemical parameters were analysed to compare the quality of the harvested water during the dry season of 2012 at 51 households using harvested water from both roofs and yards. The focus on sampling a large number of households surveyed once and thus providing a 'snapshot' analysis of a far larger number of households, complements another study (Sithole, 2014), which undertook weekly sampling at fewer households over a longer time period similar to Vohland and Barry (2009).

\section{MATERIALS AND METHODS}

\section{Study area}

The study was conducted in a smallholder farming area near Bergville in KwaZulu-Natal Province (South Africa, Fig. 1) with a total area of $11.2 \mathrm{~km}^{2}$. The ethical clearance noted that no clear identification of the area was permitted. This area is characterised by erratic and poorly distributed seasonal rainfall, with a mean annual temperature of $13^{\circ} \mathrm{C}$ (1901-1999), and mean annual precipitation of $710 \mathrm{~mm} \cdot \mathrm{y}^{1}$. This was much lower than the mean annual potential evaporation of $1750 \mathrm{~mm} \cdot \mathrm{y}^{-1}$ (Kosgei et al., 2007) resulting in an average annual water deficit of $1040 \mathrm{~mm} \cdot \mathrm{y}^{-1}$ (approx. 146\% higher than the annual rainfall). The wet season begins in October and ends in March, and typically $90 \%$ of the annual rainfall occurs in this period. Domestic and agricultural water shortages are most severe during dry winter months (from May to September). Traditionally, the community relies on rain-fed agriculture and the sources of drinking water are wells and boreholes, which are located at relatively large distances $(>500 \mathrm{~m})$ from the households. It is to fulfil the needs for water for both domestic and agricultural use that rainwater harvesting (RWH) has been introduced to the community. The first structures were built in 2004 in the framework of the smallholder system innovation (SSI) research project (Rockström et al., 2004), aimed at investigating the benefits of harvesting water from yards and within cropped fields for water availability and food production (Kosgei et al., 2007). Owing to the success of SSI and the willingness of the rural community to adopt RWH technologies, in 2011 additional RWH storage tanks were installed at 51 households to harvest water from either roofs or yards and to store it, with subsidies provided by the South African Government, through the erstwhile Department of Water Affairs. The 51 households harvest water from yards and roofs. The vast majority (47) of the roofs were constructed from metal sheets. However, three roofing systems made of tiles and one constructed from thatch were also considered for the purpose of comparison, despite data being very limited. Typically, the metal roof sheets used are galvanised with zinc and range widely from new $(n=5)$ to highly oxidised $(n=3)$ sheets. The harvested water was, in all cases, stored in $5000 \mathrm{~L}$ cylindrical plastic tanks (Fig. 2A). Tanks receiving water from yards were buried underground, while those that received water from roofs were placed above ground. In this resource-poor area, harvesting systems are simple, consisting only of gutters and downpipes leading directly to the storage tank (Fig. 2B). First-flush filters are not used and the government subsidy covered the tanks only, not any of the related infrastructure. The majority of the households had two tanks for collecting the roof water and two tanks for collecting the yard water.

Water harvested from roof tops is mostly used for domestic purposes, whilst that harvested from yards is intended for food gardening later in the year. However, several households have reported that in the dry winter months water harvested from the yard is used for domestic purposes. Consequently, concerns have been raised regarding the quality of water, relative to its intended use.

\section{Sampling methods}

The sampling of the harvested water occurred once only, on April 12, 2012, at the onset of the dry winter season, a period during which the water harvested during the previous wet months is being intensively used by smallholders. A total of 80 water samples were collected directly from the plastic storage tanks with water available at 34 households; the remaining 17 households having already utilised the harvested water or having faulty equipment. Forty-two samples were yardgenerated water and thirty-five from iron-sheet rooftops. The data from tiled and thatched roofs, despite being very limited ( $n=2$ and 1, respectively), were utilised for comparison. Data from analysis of a community borehole and a dam were also included for comparative purposes.

Yard tanks were situated underground and sampled at a depth at which water is usually drawn for use, i.e., in the middle of the existing water column of the tank, while for aboveground tanks storing roof water, the water was assessed using taps situated at the bottom of the tanks. Two $500 \mathrm{~mL}$ samples were collected from each tank, one for the evaluation of selected physical parameters and one for chemical parameters. Immediately after collection, the samples for chemical analysis were stored in the dark at $4^{\circ} \mathrm{C}$ and transported back to the laboratory located $200 \mathrm{~km}$ away from the study site. A drop of hydrochloric acid $(\mathrm{HCl}) 0.01 \mathrm{M}$ was added to $100 \mathrm{~mL}$ sub-samples collected for dissolved organic carbon (DOC) evaluation. To account for any volume effect on sample concentrations, the depth of the water present in the storage tanks was measured using a measuring tape and an estimation of total storage at the time of sampling was made. Interviews were conducted at each household to gather information on the household characteristics. These included the number of people and livestock (cattle, chickens, dogs, horses, pigs, goats and sheep) and the intended use of the harvested water. Ethical approval to conduct the experiment was obtained through the 

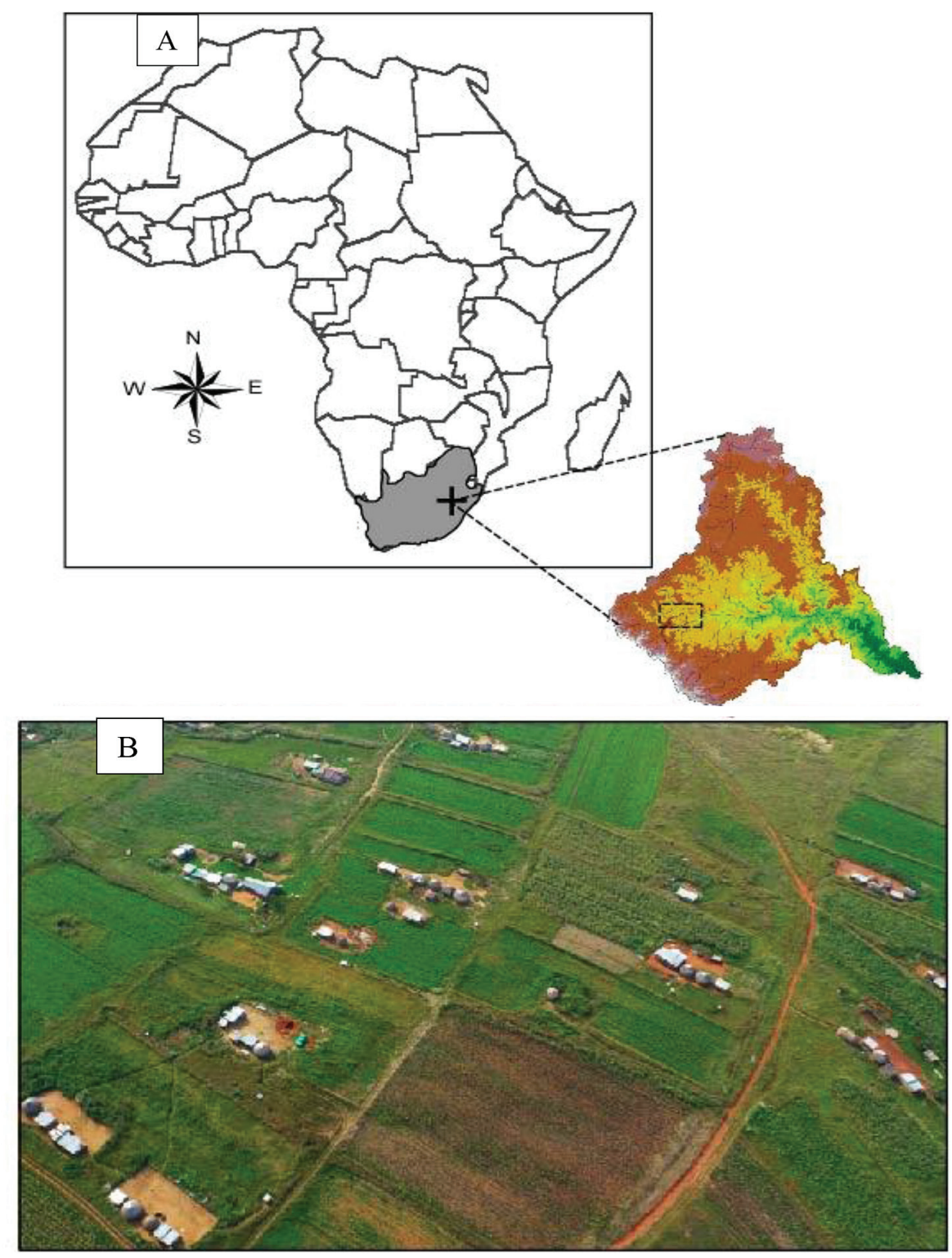

Figure 1

(A) Location of the study area in the uplands of the Thukela basin in KwaZulu-Natal, South Africa (B) view of the typical homestead layout.
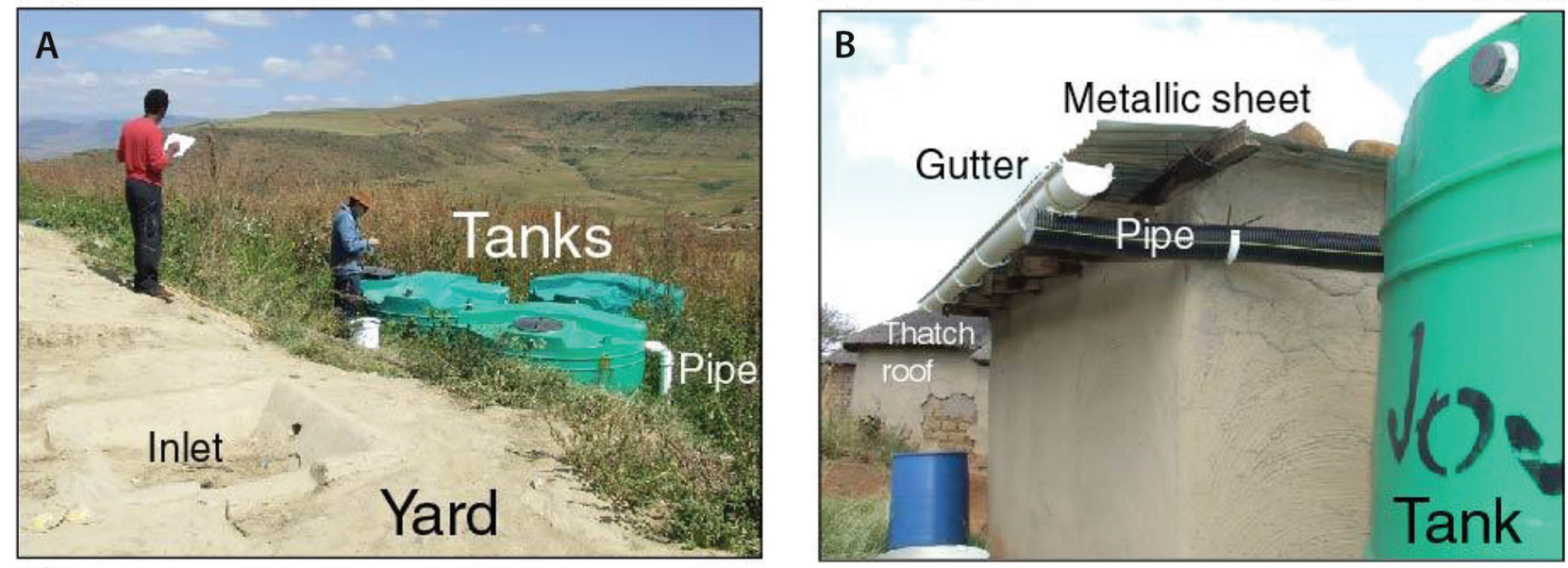

Figure 2

The water-harvesting techniques found at the study area (A) harvesting from yard; B) harvested from roof. 
prescribed procedures at the University of KwaZulu-Natal. Considering the small sample size for thatch and tile roofs, statistical analyses are reported for metal roofs only.

\section{Determining the quality of the harvested rainwater}

Water samples were analysed for water quality parameters including turbidity, electrical conductivity, $\mathrm{pH}$, dissolved organic carbon (DOC), sulphates $\left(\mathrm{SO}_{4}^{2-}\right)$, phosphates $\left(\mathrm{PO}_{4}^{-3}\right)$, nitrates $\left(\mathrm{NO}_{3}^{-}\right)$, aluminium $(\mathrm{Al})$, boron $(\mathrm{B})$, magnesium $(\mathrm{Mg})$, sodium $(\mathrm{Na})$, nickel $(\mathrm{Ni})$, potassium $(\mathrm{K})$, chromium $(\mathrm{Cr})$, calcium $(\mathrm{Ca})$, manganese $(\mathrm{Mn})$, copper $(\mathrm{Cu})$, arsenic (As), cadmium $(\mathrm{Cd})$, selenium $(\mathrm{Se})$, lead $(\mathrm{Pb})$, iron $(\mathrm{Fe})$, and zinc $(\mathrm{Zn})$. A CRISON $\mathrm{NM}_{26}{ }^{+} \mathrm{pH}$ meter, a CRISON MM26 $6^{+}$turbidity meter and a HANNA HI 8733 conductivity meter were used to measure $\mathrm{pH}$, turbidity (detection limit of $0.001 \mathrm{NTU}$ ), and electrical conductivity (detection limit of $0.1 \mu \mathrm{S} \cdot \mathrm{cm}^{-1}$ ) within $48 \mathrm{~h}$ of sample collection. Water samples were shaken to suspend contaminants in the water before measuring the turbidity. Analysis of all chemical water quality parameters was carried out according to standard methods for water and wastewater examination (APHA, 1998). All elemental standard solutions were prepared from commercial reference standards, which are available at a concentration of $1000 \mathrm{mg} \cdot \mathrm{L}^{-1}$. Standards for each chemical parameter were guided by the results found in the study conducted by Zhu et al. (2004) in China to cover the range of analyte concentrations anticipated in samples. An inductively coupled-plasma emission spectrometry (ICP-OES, Varian model,
720-ES) was used to determine the concentration of $\mathrm{SO}_{4}^{2-}, \mathrm{PO}_{4}^{-3}$, $\mathrm{Al}, \mathrm{B}, \mathrm{Mg}, \mathrm{Na}, \mathrm{Ni}, \mathrm{K}, \mathrm{Cr}, \mathrm{Ca}, \mathrm{Mn}, \mathrm{Cu}, \mathrm{As}, \mathrm{Cd}, \mathrm{Se}, \mathrm{Pb}, \mathrm{Fe}$, and $\mathrm{Zn}$ with detection limits ranging between $0.05 \mu \mathrm{g} \mathrm{L}^{-1}$ for $\mathrm{Pb}$ and $1 \mu \mathrm{g} \cdot \mathrm{L}^{-1}$ for $\mathrm{K}$. DOC concentration $\left(\mathrm{DOC}_{\mathrm{C}}\right.$ ) was determined from the acidified samples with a Shimadzu TOC- $\mathrm{V}_{\mathrm{CSH}}$ analyser via a non-purgeable organic carbon method and with a detection limit of $4 \mu \mathrm{g} \cdot \mathrm{L}^{-1}$. Considering that the harvested water was kept for domestic purposes (cooking, drinking, dish washing and clothes laundering) the results of analysis were compared with the WHO (2011) drinking water guidelines to determine if the quality of the water was sufficient for its intended use.

The independent samples $t$-test at $P<0.05$ was applied to the data to compare the quality of the rainwater harvested from yards and hut roofs in order to determine whether there is statistical evidence that the associated variable means are significantly different.

\section{RESULTS AND DISCUSSION}

\section{Impact of harvesting methods on the quality of the harvested water}

\section{Turbidity, electrical conductivity and $\mathrm{pH}$}

The average turbidity of samples collected across all roof types was $0.093 \mathrm{NTU}(n=38)$, with values ranging from 0.04 to $0.13 \mathrm{NTU}$. The water from metallic roofs exhibited the highest turbidity ( $0.11 \mathrm{NTU}, n=35)$ followed by tile roof

TABLE 1

Mean (minimum-maximum) values for selected physical and chemical characteristics of the rainwater harvested from roofs and yards. Guideline values for drinking water follow WHO (2011). S: significant difference between roof and yard water at $P<0.05$; NS: not significant.

\begin{tabular}{|c|c|c|c|c|c|c|c|c|}
\hline & \multicolumn{3}{|c|}{ Roof } & \multirow[t]{2}{*}{ Yard } & \multirow[t]{2}{*}{ Dam } & \multirow[t]{2}{*}{ Well } & \multirow[t]{2}{*}{ WHO } & \multirow[t]{2}{*}{$t$ test } \\
\hline & Metallic & Thatch & Tile & & & & & \\
\hline$n=$ & 35 & 1 & 2 & 42 & 1 & 1 & & \\
\hline Turbidity (NTU) & $0.11(0.03-1.08)$ & 0.04 & 0.13 & $0.11(0.3-0.68)$ & 0.04 & 0.03 & 5 & NS \\
\hline $\mathrm{EC}\left(\mu \mathrm{S} \cdot \mathrm{cm}^{-1}\right)$ & $15.5(8.30-49.1)$ & 18 & 15.4 & $65(36.6-127.4)$ & 61.9 & 20.4 & NA & S \\
\hline $\mathrm{pH}$ & $6.66(6.30-7.49)$ & 6.3 & 6.7 & $6.9(6.3-7.1)$ & 6.4 & 6.7 & NA & S \\
\hline $\mathrm{Al}\left(\mathrm{mg} \cdot \mathrm{L}^{-1}\right)$ & $0.17(0-2.56)$ & 0.07 & 0.17 & $1.53(0-8.3)$ & $<\mathrm{DL} \dagger$ & 0.01 & 0.1 & $\mathrm{~S}$ \\
\hline As $\left(\mathrm{mg} \cdot \mathrm{L}^{-1}\right)$ & $0.04(0-1.01)$ & $<\mathrm{DL} \dagger$ & 0.04 & $0.01(0-0.04)$ & 0.01 & 0.01 & 0.01 & S \\
\hline $\mathrm{B}\left(\mathrm{mg} \cdot \mathrm{L}^{-1}\right)$ & $0.08(0-1.10)$ & 0.07 & 0.08 & $0.02(0-0.26)$ & 0.02 & 0.01 & 0.7 & S \\
\hline $\mathrm{Ca}\left(\mathrm{mg} \cdot \mathrm{L}^{-1}\right)$ & $2.03(0.1-9.30)$ & 1.08 & 2.06 & $9.6(0.1-29.8)$ & 8.35 & 1.67 & 500 & S \\
\hline $\mathrm{Cd}\left(\mathrm{mg} \cdot \mathrm{L}^{-1}\right)$ & $0.04(0-1.02)$ & $<\mathrm{DL} \dagger$ & 0.03 & $0.001(0-0.03)$ & $<\mathrm{DL} \dagger$ & $<\mathrm{DL} \dagger$ & 0.003 & S \\
\hline $\mathrm{Cr}\left(\mathrm{mg} \cdot \mathrm{L}^{-1}\right)$ & $0.03(0-1.00)$ & $<\mathrm{DL} \dagger$ & 0.03 & $0.002(0-0.03)$ & $<\mathrm{DL} \dagger$ & $<\mathrm{DL} \dagger$ & 0.05 & S \\
\hline $\mathrm{Cu}\left(\mathrm{mg} \cdot \mathrm{L}^{-1}\right)$ & $0.02(0-0.90)$ & $<\mathrm{DL} \dagger$ & 0 & $0(0-0.13)$ & $<\mathrm{DL} \dagger$ & $<\mathrm{DL} \dagger$ & 2 & $S$ \\
\hline $\operatorname{DOC}\left(\mathrm{mg} \cdot \mathrm{L}^{-1}\right)$ & $0.35(0-5.71)$ & 4 & 0.3 & $2.06(0-10.03)$ & 1.12 & $<\mathrm{DL} \dagger$ & NA & S \\
\hline $\mathrm{Fe}\left(\mathrm{mg} \cdot \mathrm{L}^{-1}\right)$ & $0.13(0-1.25)$ & 0.08 & 0.13 & $1.29(0-4.56)$ & 0.1 & 0.03 & NA & S \\
\hline $\mathrm{K}\left(\mathrm{mg} \cdot \mathrm{L}^{-1}\right)$ & $0.10(0.01-1.05)$ & 0.38 & 0.1 & $0.9(0.01-2.7)$ & 0.16 & 0.09 & NA & $\mathrm{S}$ \\
\hline $\mathrm{Mg}\left(\mathrm{mg} \cdot \mathrm{L}^{-1}\right)$ & $0.28(0-1.38)$ & 0.45 & 0.28 & $1.3(0.05-6.2)$ & 5.35 & 0.91 & NA & $\mathrm{S}$ \\
\hline $\mathrm{Mn}\left(\mathrm{mg} \cdot \mathrm{L}^{-1}\right)$ & $0.021(0-0.87)$ & $<\mathrm{DL} \dagger$ & 0 & $0.018(0-0.20)$ & $<\mathrm{DL} \dagger$ & $<\mathrm{DL} \dagger$ & 0.1 & NS \\
\hline $\mathrm{Na}\left(\mathrm{mg} \cdot \mathrm{L}^{-1}\right)$ & $0.45(0.1-3.05)$ & 0.37 & 0.46 & $4.25(0.05-10.07)$ & 4.05 & 2.59 & NA & S \\
\hline $\mathrm{Ni}\left(\mathrm{mg} \cdot \mathrm{L}^{-1}\right)$ & $0.03(0-1.00)$ & 0.001 & 0.03 & $0.00(0-0.03)$ & $<\mathrm{DL} \dagger$ & $<\mathrm{DL} \dagger$ & 0.07 & $S$ \\
\hline $\mathrm{NO}_{3}^{-}\left(\mathrm{mg} \cdot \mathrm{L}^{-1}\right)$ & $1.70(1.0-4.60)$ & 1.4 & 1.7 & $2.73(1.1-4.5)$ & 0.6 & 1.7 & 50 & NS \\
\hline $\mathrm{Pb}\left(\mathrm{mg} \cdot \mathrm{L}^{-1}\right)$ & $0.02(0-0.86)$ & $<\mathrm{DL} \dagger$ & 0 & $<\mathrm{DL} \dagger$ & $<\mathrm{DL} \dagger$ & $<\mathrm{DL} \dagger$ & 0.01 & S \\
\hline $\mathrm{PO}_{4}^{-3}\left(\mathrm{mg} \cdot \mathrm{L}^{-1}\right)$ & $0.28(0.2-0.43)$ & 0.41 & 0 & $0.31(019-0.77)$ & 0.26 & 0.3 & NA & NS \\
\hline $\mathrm{Se}\left(\mathrm{mg} \cdot \mathrm{L}^{-1}\right)$ & $0.02(0-0.82)$ & $<\mathrm{DL} \dagger$ & 0 & $<\mathrm{DL} \dagger$ & $<\mathrm{DL} \dagger$ & $<\mathrm{DL} \dagger$ & 0.04 & $\mathrm{~S}$ \\
\hline $\mathrm{SO}_{4}^{2-}\left(\mathrm{mg} \cdot \mathrm{L}^{-1}\right)$ & $0.30(0.25-0.38)$ & 0.38 & 0 & $0.43(0.3-1.9)$ & 0.28 & 0.25 & 400 & NA \\
\hline $\mathrm{Zn}\left(\mathrm{mg} \cdot \mathrm{L}^{-1}\right)$ & $2.20(0.01-4.57)$ & 0.29 & 2.17 & $1.78(0-3.8)$ & 0.02 & 0.08 & NA & NS \\
\hline
\end{tabular}

$75 \%$ of the samples above the WHO (2011) limit for drinking water; $\dagger<D L$ : below detection limit. 
(0.13 NTU, $n=2)$ and thatch roof (0.04 NTU, $n=1)$ (Table 1). Average turbidity of rainwater samples collected from yards did not significantly differ $(P<0.05)$ to that for metallic roofs (0.11 NTU, $n=42$ ) (Table 1$)$. The water turbidity was in both cases within the WHO (2011) acceptable limit of 5 NTU. The turbidity level observed in the present study was $69.1 \%$ to $98.5 \%$ lower than the values reported in the literature, for instance by Zhu et al. (2004) for rainwater harvested from roofs and yards in China, probably indicating the extent of sediment settling in the tanks by April.

The average electrical conductivity (EC) for roofs was highest in the water from thatch roofs $\left(18.0 \mu \mathrm{Scm}^{-1} ; n=\right.$ 1) and showed little variation between metallic and tile roofs (15.4 and $15.5 \mu \mathrm{S} \cdot \mathrm{cm}^{-1}$, respectively), these differences not being significant at $P<0.05$. EC was found to vary significantly $(P<0.05)$ between roof- and yard-harvested water, with the highest EC being observed in the water from yards $\left(65.4 \mu \mathrm{S} \cdot \mathrm{cm}^{-1} ; n=42\right)$. This trend is shown using boxand-whisker plots for EC in Fig. 3A. Similarly water samples from the downstream dam exhibited significantly higher EC $\left(61.9 \mu \mathrm{S} \cdot \mathrm{cm}^{-1}\right)$ than in roof water, which can be explained by lateral transportation of solids through surface runoff. Of the three parameters (turbidity, EC and $\mathrm{pH}$ ), $\mathrm{pH}$ was the least sensitive to the type of harvesting method. The variation in $\mathrm{pH}$ (6.4-6.9) between water samples from roofs and those from yards is presented in Fig. 3B. Although the mean for yard-harvested water was higher at 6.9, the rainwater from all samples (roof, yard, dam and well) was slightly acidic. These $\mathrm{pH}$ values, which were all in the near-neutral range $(6.0<\mathrm{pH}$ $<7.9)$, and did not vary significantly between the sources of water, were in accordance with previous studies on the subject, such as Lee et al. (2012) and Efe (2006), and met the WHO standard for drinking water of $6.5<\mathrm{pH}<8.5$. However, $\mathrm{pH}$ is rarely reported to be of concern at the levels found in drinking water by WHO (2011). Similarly, the water from both the tile $(n=3)$ and thatch $(n=1)$ roofs met the WHO (2011) standards for turbidity $\mathrm{EC}$ and $\mathrm{pH}(6.5<\mathrm{pH}<8.5)$, with values close to those observed for metallic roofs. The water sample from the thatch roof exhibited a turbidity which was much lower than that of the harvested water from metallic roofs and yards, but of the same order of magnitude as the dam and borehole water; the level of significance of these differences could not be tested due to the low sample size.

\section{Dissolved organic carbon}

The average DOC concentration showed little variation between the water harvested from metallic and from tile roofs $\left(0.3-0.35 \mathrm{mg} \cdot \mathrm{L}^{-1}\right)$. DOC concentration was as high as $4.0 \mathrm{mg} \cdot \mathrm{L}^{-1}$ $(n=1)$ in the water originating from thatch roofs (Fig. 3c), probably as the result of the dissolution of the fresh organic matter from the thatching grass. DOC concentration between metallic roof $\left(0.35 \mathrm{mg} \cdot \mathrm{L}^{-1} ; n=35\right)$ and yard water $\left(2.06 \mathrm{mg} \cdot \mathrm{L}^{-1}\right.$; $n=42$ ) reflected a 5.9 -fold difference, significant at $p<0.05$. The greater DOC content in the yard water was expected since the rain erodes the organic-rich surface soil horizon from the yard and washes the fresh organic matter from animal droppings and/or wastewater into receiving tanks. The DOC concentration in the tanks receiving runoff from yards was significantly lower than values recorded at the same site by
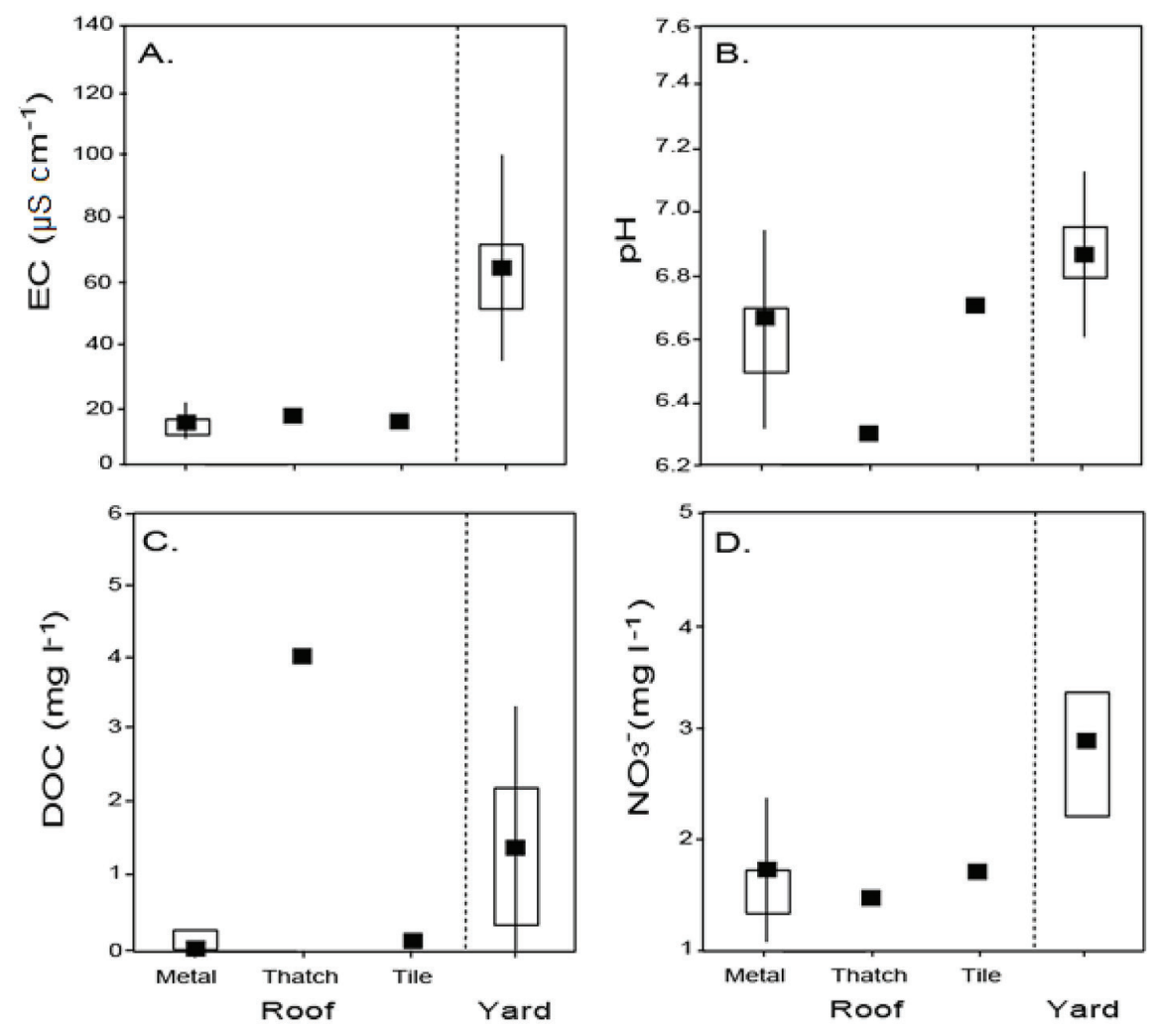

Figure 3

Box plots (median, 1st, 3rd and 1st and 9th deciles) for electric conductivity (A), $\mathrm{pH}(\mathrm{B})$, dissolved organic carbon (C) and nitrate (D) as a function of the water-harvesting method (roof vs yard) and the roof material (metal, thatch and tile). 
Chaplot and Ribolzi (2013) for overland flow exiting grassland plots $\left(\mathrm{DOC}=11.9 \pm 0.8 \mathrm{mg} \cdot \mathrm{L}^{-1}\right)$, but values were in accordance with what has been found by these authors for groundwater $\left(\mathrm{DOC}=2.3 \pm 0.6 \mathrm{mg} \cdot \mathrm{L}^{-1}\right)$. This difference may be due to organic matter decomposition in the tanks.

Since a DOC concentration over $5 \mathrm{mg} \cdot \mathrm{L}^{-1}$ poses a health risk, both the roof and yard waters were potable on average. However, one of the metallic roof samples (i.e. $2.8 \%$ of all samples) and 4 yard samples (9.5\%) exceeded the $5 \mathrm{mg} \mathrm{L}^{-1}$ limit. The high proportion of biodegradable components present in these is likely to decompose quickly during storage as it constitutes a main source of energy for heterotrophic bacteria (Gregorich et al., 2000). In contrast, the groundwater sample showed a DOC content below detection, while the DOC content in the dam water was $1.12 \mathrm{mg} \cdot \mathrm{L}^{-1}$, i.e., close to that of the yard water.

\section{Nitrate, sulphate and phosphate}

The average $\mathrm{NO}_{3}^{-}$concentration varied greatly from $1.4-1.7 \mathrm{mg} \cdot \mathrm{L}^{-1}\left(\right.$ mean $\left.=1.60 \mathrm{mg} \cdot \mathrm{L}^{-1}, n=38\right)$ in the rainwater harvested from all roof types, and from $1.10-4.50 \mathrm{mg} \cdot \mathrm{L}^{-1}$ (mean $\left.=2.74 \mathrm{mg} \cdot \mathrm{L}^{-1}, n=42\right)$ in the yard rainwater, which corresponded to a significant difference at the $p<0.05$ level. The higher nitrate concentration in the yard water could result from the contamination of runoff by livestock faeces lying on the surface. However, the highest value, i.e., $4.6 \mathrm{mg} \cdot \mathrm{L}^{-1}$ among the samples was, surprisingly, from a single sample from a tank harvesting rain from a metallic roof, most likely the result of contamination at that site. The $\mathrm{NO}_{3}^{-}$content in rainwater harvested from all roof types and yards met the WHO (2011) standard for drinking water of $10 \mathrm{mg} \cdot \mathrm{L}^{-1}$ (Table 1) The average $\mathrm{SO}_{4}^{2-}$ concentration was $0.30(0.25-0.38) \mathrm{mg} \cdot \mathrm{L}^{-1}$ for water from metallic roofs and increased to $0.46(0.26-1.87) \mathrm{mg} \cdot \mathrm{L}^{-1}$ for yard rainwater, which corresponded to a $50 \%$ increase, significant at $p<0.05$ level. The water from the thatch roof was $0.38 \mathrm{mg} \cdot \mathrm{L}^{-1}$, while that from the tile roof exhibited an $\mathrm{SO}_{4}^{2-}$ content below detection limit of $0.05 \mu \mathrm{g} \cdot \mathrm{L}^{-1}$. The water from all sources met the WHO (2011) standard for drinking water of $400 \mathrm{mg} \cdot \mathrm{L}^{-1}$. The $\mathrm{SO}_{4}^{2-}$ concentration was also lower than that reported by Zhu et al. (2004) in China for rainwater harvested from both metallic roofs and yards, which is more likely to be associated with air pollution. The average $\mathrm{PO}_{4}^{-3}$ concentration was $0.28(0.2-0.43) \mathrm{mg} \cdot \mathrm{L}^{-1}$ for roof water and $0.32(0.19-0.77) \mathrm{mg} \cdot \mathrm{L}^{-1}$ for yard water, but this difference was not significant at $p<0.05$ level. The values increased to $0.41 \mathrm{mg} \cdot \mathrm{L}^{-1}$ for the thatch roof water sample and decreased to below the detection limit of $0.05 \mu \mathrm{g} \cdot \mathrm{L}^{-1}$ for the two samples from tiled roofs. The borehole water showed contents close to those found in the water harvested from both metallic and thatch roofs (Table 1).

\section{Other chemical elements}

The greatest $\mathrm{Na}$ concentrations were found in the yard, borehole and dam water $\left(\mathrm{Na}>2 \mathrm{mg} \cdot \mathrm{L}^{-1}\right)$ and the lowest values were observed in the roof water, irrespective of the roofing material (Table 1). Sodium concentration of all samples was found to be much lower than $200 \mathrm{mg} \cdot \mathrm{L}^{-1}$, the concentration at which unacceptable taste will emerge (WHO, 2011). The greater $\mathrm{Na}$ content in the dam and borehole waters was intuitive as longer time scales allow $\mathrm{Na}$ dissolution in the groundwater to occur (Hooper et al., 1990). The high Na concentration in the yard water (Table 1) was surprising and needs to be further investigated.

The rainwater harvested from metallic roofs exceeded the WHO (2011) limit for drinking water for $\mathrm{Al}, \mathrm{B}, \mathrm{Se}, \mathrm{Ni}$, $\mathrm{Pb}, \mathrm{Cu}, \mathrm{As}, \mathrm{Cd}, \mathrm{Cr}$ and $\mathrm{Mn}$ in at least 1 sample, and for $\mathrm{Al}, \mathrm{B}, \mathrm{Se}$ and $\mathrm{Cd}$ in the case of $75 \%$ or more of the water samples. At the same time, approximately $75 \%$ of the yard water samples exceeded the WHO (2011) threshold for Al only. The significantly higher concentrations in all metals, except $\mathrm{Al}$ and $\mathrm{Fe}$ in the roof water compared to the yard water (Table 1, Fig. 4, Fig. 5A), could be a result of dissolution of these elements from the metal roof sheets, as they deteriorate over time. In contrast, both the thatch and tile roof water showed acceptable levels for the selected chemical elements, except for As in the case of tile roofs. The significantly higher concentration of $\mathrm{Al}, \mathrm{Fe}$ and $\mathrm{Zn}$ in the yard water is more difficult to explain, since both the dam and borehole water exhibited much lower concentrations. It is possible that metallic pollution on the yard surface associated with metallic roofs could have occurred, with $\mathrm{Al}, \mathrm{Fe}$ and $\mathrm{Zn}$ being adsorbed by organo-metal complexes present there.

Overall, the water harvested from metallic roofs showed a relatively balanced composition with respect to the selected metallic elements, with an average concentration between 0.03 and $0.1 \mathrm{mg} \cdot \mathrm{L}^{-1}$, except for a peak of $1 \mathrm{mg} \cdot \mathrm{L}^{-1}$ in the case of $\mathrm{Zn}$, probably associated with deterioration of the roof material. The distribution of the metal concentrations was much less balanced in the yard water, with, on the one hand, relatively low concentrations for $\mathrm{Cd}, \mathrm{Cr}, \mathrm{Ni}, \mathrm{As}, \mathrm{Pb}, \mathrm{Se}, \mathrm{Mn}$ and $\mathrm{Cu}$ and, on the other hand higher levels of $\mathrm{Al}, \mathrm{B}, \mathrm{Fe}$ and $\mathrm{Zn}$. Both the metallic and yard waters exhibited high $\mathrm{Ca}, \mathrm{NO}_{3}^{-}$, and low $\mathrm{PO}_{4}^{-3}$ and $\mathrm{SO}_{4}^{2-}$ levels, while the roof water showed much lower $\mathrm{Mg}, \mathrm{Ca}, \mathrm{SO}_{4}^{2-}$ and $\mathrm{Na}$ levels than the yard water (Fig. 5B, Table 1).

\section{Impact of household characteristics on the quality of the water harvested from yards}

Most of the chemical elements were significantly correlated with the selected household characteristics (Table 2). None of the water quality parameters were significantly correlated with the number of people, sheep and horses in the household, with Pearson $r$ coefficients ranging from -0.31 to 0.32 . In contrast, the number of pigs showed the highest correlation to most of the elements $\left(\mathrm{SO}_{4}^{2-}: r=0.78\right.$; $\mathrm{B}: r=0.74$; DOC: $r=0.52$; $\mathrm{NO}_{3}: r=0.44$; and both $\mathrm{Al}$ and $\mathrm{K}$ with $r=0.42$ ) followed by the number of chickens, dogs, goats and cattle (Table 2).

The reasons for high correlation between the number of livestock and water quality are not well documented in the literature. The most likely reason lies in the droppings of the livestock, particularly with regard to nitrogen, phosphorus and potassium (Hooda et al., 2000) being washed into the tanks. Another link has also been made between livestock and other water quality parameters, not investigated here, such as bacteria, viruses and protozoa (Hooda et al., 2000). Microbial sampling and analysis was beyond the scope of this study and requires further investigation in the future. The higher correlation with the number of pigs than cattle can be explained by the fact that pigs are kept in the near vicinity of the huts, mostly in the yard itself, while cows graze elsewhere. 

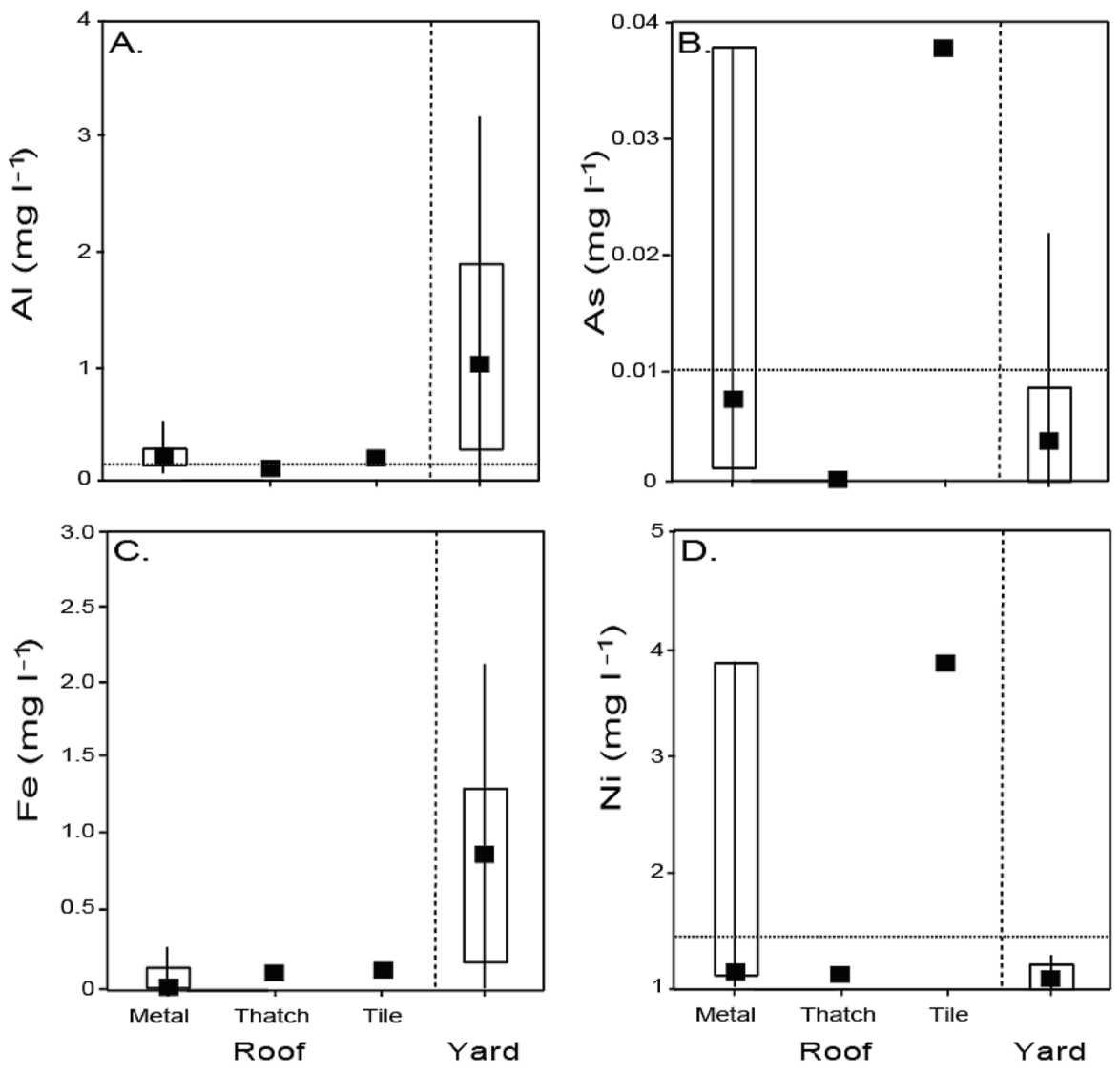

Figure 4

Box plots (median, 1st, 3rd and 1st and 9th deciles) for Al (A), As (B), Fe (C) and Ni (D) as a function of the water-harvesting method (roof vs yard) and the roof material (metal, thatch and tile). Horizontal dotted lines correspond to WHO (2011) threshold values.

TABLE 2

Correlation between household characteristics and water quality parameters in RWH from yards. Underlined values indicates positive and significant correlation at $p<0.05$ level.

\begin{tabular}{|c|c|c|c|c|c|c|c|c|}
\hline R & Human & Cattle & Chicken & Dog & Goat & Sheep & Pig & Horse \\
\hline $\mathrm{Na}$ & -0.06 & 0.20 & $\underline{0.45}$ & -0.02 & 0.30 & 0.10 & -0.02 & 0.32 \\
\hline K & 0.26 & 0.30 & $\underline{0.53}$ & $\underline{0.42}$ & $\underline{0.53}$ & 0.35 & $\underline{0.42}$ & -0.06 \\
\hline $\mathrm{Ca}$ & -0.31 & -0.18 & -0.20 & 0.02 & -0.06 & 0.19 & 0.03 & -0.15 \\
\hline $\mathrm{Mg}$ & 0.03 & 0.25 & $\underline{0.44}$ & -0.03 & $\underline{0.44}$ & -0.01 & 0.02 & -0.02 \\
\hline B & -0.12 & -0.08 & 0.02 & $\underline{0.58}$ & 0.1 & 0.18 & $\underline{0.74}$ & 0.07 \\
\hline $\mathrm{Fe}$ & 0.07 & $\underline{0.44}$ & $\underline{0.50}$ & 0.24 & $\underline{0.62}$ & 0.21 & $\underline{0.36}$ & 0.12 \\
\hline $\mathrm{Al}$ & 0.02 & 0.16 & 0.36 & 0.27 & $\underline{0.39}$ & 0.29 & $\underline{0.42}$ & 0.02 \\
\hline $\mathrm{SO}_{4}{ }^{2-}$ & -0.11 & -0.15 & -0.05 & $\underline{0.59}$ & 0.07 & 0.24 & $\underline{0.78}$ & -0.04 \\
\hline $\mathrm{EC}$ & -0.15 & -0.09 & 0.07 & 0.09 & 0.11 & 0.26 & 0.18 & -0.03 \\
\hline $\mathrm{N}$ & 0.08 & -0.17 & 0.12 & 0.09 & 0.21 & 0.02 & $\underline{0.44}$ & -0.31 \\
\hline $\mathrm{pH}$ & 0.23 & -0.05 & -0.07 & 0.06 & 0 & 0.15 & 0.05 & 0.21 \\
\hline DOC & -0.23 & 0.05 & 0.27 & 0.46 & 0.27 & -0.02 & $\underline{0.52}$ & 0.21 \\
\hline
\end{tabular}

\section{CONCLUSION}

While RWH is being increasingly adopted by smallholders from the developing world to meet the demand for freshwater, especially in times of shortage, such as during dry spells or droughts, a number of unresolved issues remain before this can be considered a safe and sustainable supply. One of them concerns the quality of the harvested water, with several questions regarding the impact of harvesting method, storage technology and household characteristics.

RWH experiments in rural areas which consider the quality of harvested water are still rare. Thus, this study makes a contribution to this information gap. Three main trends regarding the physical and chemical quality of the 
A.

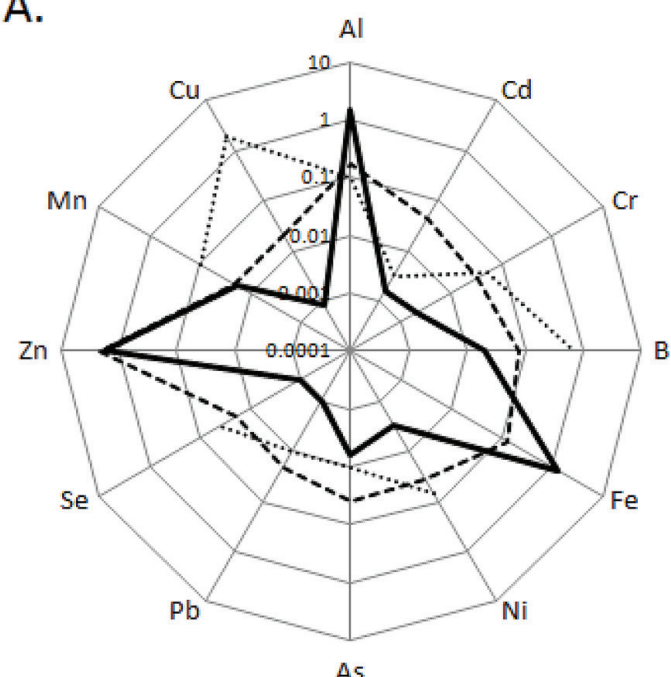

B.

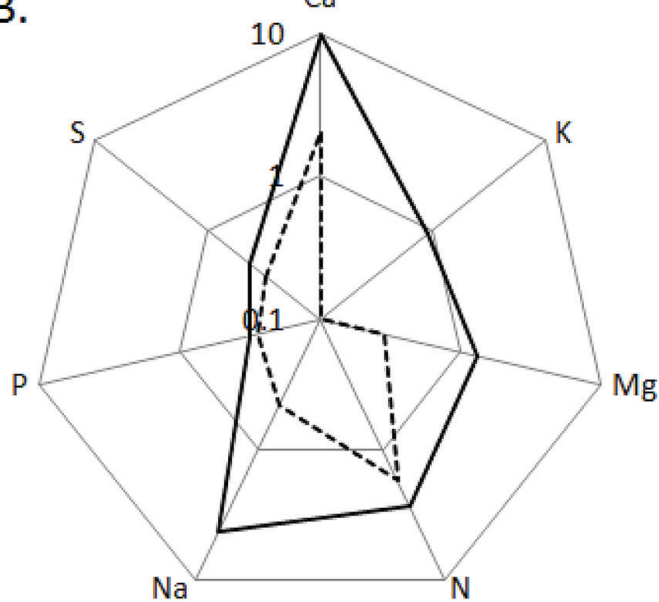

Figure 5

Diagrams showing the average concentration of metallic elements $(A)$ and nutrients $(B)$; large dotted line $=$ water harvested from yards; continuous line = roof water; fine dotted line = WHO (2011) threshold values.

water harvested from yards and roofs of the 51 households in the KwaZulu-Natal Province of South Africa used in this study can be observed. Despite a relatively low number of samples, the first finding is that, while both sources of water showed acceptable physical characteristics with regard to the WHO (2011) standards for drinking water, $75 \%$ or more of the water samples from roof harvesting showed excessive concentrations of Se, $\mathrm{Al}$ and $\mathrm{Cd}$. The second trend concerns the overall characteristics of the water harvested from roofs and yards:

- In comparison to water from yards, water from metallic roofs showed lower concentrations of $\mathrm{K}, \mathrm{DOC}, \mathrm{PO}_{4}^{-3}$ and $\mathrm{SO}_{4}^{2-}$ but higher Zn.

- Despite very low sample numbers, water from thatch roofs had the lowest concentration of all chemical elements except $\mathrm{DOC}$ and nutrients $\left(\mathrm{PO}_{4}^{-3}, \mathrm{SO}_{4}^{2-}, \mathrm{NO}_{3}^{-}, \mathrm{Mg}\right)$.

- In comparison to water from roofs, water from yards exhibited high levels of nutrients, $\mathrm{Ca}, \mathrm{Na}$ and DOC.

Finally, there was a tendency for the concentration of nutrients and dissolved organic carbon content of yard water to increase with the number of pigs in the household, while the number of livestock and people seemed to have little impact.

These results point to the need for post-harvesting treatment, such as the use of ceramic filters before consumption (Simonis et al., 2014). However, these initial results need to be confirmed and there remain several issues to be investigated to provide a more comprehensive assessment of water quality from RWH. The biological aspects of water quality (e.g. Abdulla and Al-Shareef, 2009; Sazakli et al., 2007) should be considered in the future and information on the temporal evolution of water quality should be provided to further our understanding of the mechanisms and processes associated with the quality of harvested water.

\section{ACKNOWLEDGEMENTS}

The authors are grateful to the European Union funding through the FP7 project 'Water Harvesting Technologies Revisited: Potentials for Innovations, Improvements and Upscaling in SubSaharan Africa' (Grant agreement no: 266360). Special thanks go to the Water Research Commission for their support of Project No. 2266 which enabled the sharing of equipment, protocols, knowledge and transport from Pietermaritzburg, and to the community for allowing access to their land. Finally, the authors want to thank the two anonymous reviewers and the Editor for their very valuable comments.

\section{REFERENCES}

ABDULLA FA and AL-SHAREEF AW (2009) Roof rainwater harvesting systems for household water supply in Jordan. Desalination 243 195-207. https://doi.org/10.1016/j. desal.2008.05.013

AL-KHATIB IA and ORABI M (2004) Causes of drinking water contamination in rain fed cisterns in three villages in Ramallah and Al-Bireh District in Palestine, Eastern Mediterranean. Health J. WHO 10 429-436.

AL-SALAYMAN A, AL-KHATIB TA and ARAFAT HA (2011) Towards sustainable water quality: Management of rainwater harvesting cisterns in Southern Palestine. Water Resour. Manage. 25 1721-1736. https://doi.org/10.1007/s11269-010-9771-0

BARRON J and OKWACH G (2005) Run-off water harvesting for dry spell mitigation in maize (Zea mays L.): Results from on-farm research in semi-arid Kenya. Agric. Water Manage. 74 1-21. https:// doi.org/10.1016/j.agwat.2004.11.002

BOSSIO D, JEWITT G, VAN DER ZAAG P and MAHOO H (2011) Smallholder system innovation for integrated watershed management in Sub-Saharan Africa. Agric. Water Manage. 98 (11), 1683-1686. https://doi.org/10.1016/j.agwat.2011.07.006

BULCOCK LM and JEWITT GPW (2013) Key physical characteristics used to assess water harvesting suitability. Phys. Chem. Earth 66 89-100. https://doi.org/10.1016/j.pce.2013.09.005

CHAPLOT V and RIBOLZI O (2013) Hydrograph separation to improve understanding of dissolved organic carbon dynamics in headwater catchments. Hydrol. Process. 28 5354-5366. https://doi. org/10.1002/hyp.10010

DOBROWSKY PH, VAN DEVENTER A, DE KWAADSTENIET M, NDLOVU T, KHAN S, CLOETE TE and KHAN W (2014) Prevalence of virulence genes associated with pathogenic Escherichia coli strains isolated from domestically harvested rainwater during low- and high-rainfall periods. Appl. Environ. Microbiol. 80 1633-1638. https://doi.org/10.1128/AEM.03061-13

EFE SI (2006) Quality of rainwater harvesting for rural communities of Delta State Nigeria. Environmentalist 26 175-181. https://doi. org/10.1007/s10669-006-7829-6

GREGORICH EG, LIANG BC, DRURY CF, MACKENZIE AF and MCGILL WB (2000) Elucidation of the source and turnover 
of water soluble and microbial biomass carbon in agricultural soils. Soil Biol. Biochem. 32 581-587. https://doi.org/10.1016/ S0038-0717(99)00146-7

HELMREICH B and HORN H (2009) Opportunities in rainwater harvesting. Desalination 248 118-124. https://doi.org/10.1016/j. desal.2008.05.046

HOODA PS, EDWARDS AC, ANDERSON HA AND MILler A (2000) A review of water quality concerns in livestock farming areas. Sci. Total Environ. 250 143-167. https://doi.org/10.1016/ S0048-9697(00)00373-9

HOOPER RP, CHRISTOPHERSEN N and PETERS NE (1990) Modelling streamwater chemistry as a mixture of soilwater end-members-An application to the Panola Mountain catchment Georgia USA. J. Hydrol. 116 321-343. https://doi. org/10.1016/0022-1694(90)90131-G

JAIN CK, BANDYOPADHYAY A and BHADRA A (2010) Assessment of ground water quality for drinking purpose, District Nainital Uttarakhand, India. Environ. Monit. Assess. 166 663-676. https:// doi.org/10.1007/s10661-009-1031-5

JÄRUP L (2003) Hazards of heavy metal contamination. Brit. Med. Bull. 68 167-182. https://doi.org/10.1093/bmb/ldg032

KAHINDA JM, ROCKSTRÖM J, TAIGBENU AE and DIMES J (2007) Rainwater harvesting to enhance water productivity of rainfed agriculture in the semi-arid Zimbabwe. Phys. Chem. Earth 32 1068-1073. https://doi.org/10.1016/j.pce.2007.07.011

KONG RYC, MAK MMH and WU RSS (2009) DNA technologies for monitoring waterborne pathogens: a revolution in water pollution monitoring. Ocean Coast. Manage. 52 355-358. https://doi. org/10.1016/j.ocecoaman.2009.04.011

KOSGEI JK, JEWITT GPW, LORENTZ S and KONGO V (2007) The influence of on field scale water fluxes and maize yields in semiarid environments: A case study of Potshini catchment South Africa. Phys. Chem. Earth 32 1117-1126. https://doi.org/10.1016/j. pce.2007.07.027

KUS B, KANDASAMY J, VIGNESWARAN S and SHON HK (2010) Water quality characterisation of rainwater in tanks at different times and locations. Water Sci. Technol. 61 429-439. https://doi. org/10.2166/wst.2010.824

LI X, XIE Z and YAN X (2004) Runoff characteristics of artificial catchment material for rainwater harvesting in the semi-arid regions of China. Agric. Water Manage. 65 211-224. https://doi. org/10.1016/j.agwat.2003.09.003

LEE JY, BAK G and HAN M (2012) Quality of roof-harvested rainwater - Comparison of different roofing materials. Environ. Pollut. 162 422-429. https://doi.org/10.1016/j.envpol.2011.12.005
MENDEZ CB, KLENZENDORF JB, AFSHAR BR, SIMONS MT, BARROT ME, KINNEY KA and KIRISITS MJ (2010) The effect of roofing material on the quality of harvested water. Water Res. Technol. 145 2049-2059.

PACEY A and CULLIS A (1986) Rainwater harvesting. The collection of rainfall and runoff in rural areas. Intermediate Technology Development Group, London. https://doi. org/10.3362/9781780445700

RADIADEH J, AL-ZBOON K, AL-HARAHSHEH A and AL-ADAMAT R (2009) Quality assessment of harvested rainwater for domestic uses Jordan. J. Earth Environ. Sci. 1 26-31.

ROCKSTRÖM J (2000) Water resources management in smallholder farms in Eastern and Southern Africa: An overview. Phys. Chem. Earth 25 275-283. https://doi.org/10.1016/S1464-1909(00)00015-0

SAZAKLI E, ALEXOPOULOS A and LEOTSINIDIS M (2007) Rainwater harvesting quality assessment and utilization in Kefalonia Island Greece. Water Res. 41 2039-2047. https://doi. org/10.1016/j.watres.2007.01.037

SCHIETTECATTE W, OUESSAR M, GABRIELS D, TANGHE S, HEISMEN $S$ and ABDULLI F (2005) Impact of water harvesting techniques on soil and water conservation: a case study on microcatchment in Southeastern Tunisia. J. Arid Environ. 61 297-313. https://doi.org/10.1016/j.jaridenv.2004.09.022

SIMONIS J, NDWANDWE M, BASSON A and SELEPE T (2014) Removal of selected microorganisms using silver-impregnated and coated low-cost micro-porous ceramic water filters. J. Water Sanit. Hyg. Dev. 4 37-42. https://doi.org/10.2166/washdev.2013.027

SITHOLE SS (2014) Examining the temporal variability of water quality from different rainwater harvesting systems in the Potshini sub-catchment of South Africa. MSc dissertation, University of KwaZulu-Natal. 44 pp.

STURM M, ZIMMERMANN M, SCHÜTZ K, URBAN W and HARTUNG H (2009) Rainwater harvesting as an alternative water resource in rural sites in central northern Namibia. Phys. Chem. Earth 34 776-785. https://doi.org/10.1016/j.pce.2009.07.004

VOHLAND K and BARRY B (2009) A review of in situ rainwater harvesting (RWH) practices modifying landscape functions in African drylands. Agric. Ecosyst. Environ. 131 119-127. https://doi. org/10.1016/j.agee.2009.01.010

WHO (2011) Guidelines for Drinking Water Quality Recommendations. World Health Organization, Geneva. 564 pp.

ZHU K, ZHANG L, HART W, LIU M and CHEN H (2004) Quality issues in harvested rainwater in arid and semi-arid Loess Plateau of northern China. J. Arid Environ. 57 487-505. https://doi. org/10.1016/S0140-1963(03)00118-6 